\title{
Awareness of Human Resource Accounting in Ghana: Evidence from Tertiary Students
}

\author{
Philip Opoku \\ Department of Accounting \& Finance, Valley View University-Ghana
}

\begin{abstract}
This paper focused on the awareness of Human Resource Accounting among Tertiary students in the Greater Accra Region of Ghana. Quantitative research approach was used in the study. The study used convenient sampling technique to select 20 Tertiary Institution among the 37 topnotch and highly rated tertiary institutions in Ghana and distributed selfcontracted questionnaire among 300 students from the sampled Tertiary Institutions, out of which 200 were retrieved, only 180 was valid for further analysis. Inferential statistics were used to analyze the data through Statistical Product and Service Solutions (SPSS, 20.0) software. Results showed that there is 83\% level of awareness of Human Resource Accounting among tertiary students in the greater Accra Region of Ghana. The findings implies that even though there is an awareness among tertiary students, the understanding on Human resource accounting is limited. Judging from the findings the researcher recommends that Human Resource Accounting should be encapsulated into the courses of studies for Commerce, Management studies and other Finance related programs at the various tertiary institution.
\end{abstract}

\section{INTRODUCTION}

$\mathrm{T}$ he Accounting Profession is now evolving worldwide from the normal financial statement reporting to a comprehensive statement that inculcates financial and nonfinancial elements. This kind of reporting enhances and projects organisations' image to be socially responsible.

According to Mohammed, Bhatti, Jariko \& Zehri (2013), to ensure any organisation's growth and development, employee efficiency must be accounted for in the financial statement. Notwithstanding this, other areas of an organisation cannot be operationally effective without human involvement. Human behavior such as group loyalty, skill, motivation, and capacity for successful interaction, communication, and decision-making mark the survival of every organization (Collings, 2015).

An organisation's resources are categorized into men, materials, machinery, money, and processes. These resources can be grouped into two main categories: animate and inanimate. Human resources, sometimes known as men, are believed to be animate resources. Materials, machines, money, and procedures, come under the inanimate or physical resources (Wardani, 2017).

Presently, accounting for human resources has received tremendous attention worldwide (Gallagher \& Hutchinson, 2018; Kamoche2011; Mello2014; Wardani, 2017). This necessitated the need to investigate the level of awareness of human resource accounting among tertiary students. This paper further investigates whether human resource accounting is a major course among the courses of studies for students pursuing management studies and commerce in various tertiary institutions. A few research has been conducted in this field to determine the level of human resource accounting awareness among tertiary students in Ghana. This research focused on human resource accounting, the objective, goals, and importance.

Human resource accounting is gaining grounds worldwide in recent times, but management accounting systems and financial accounting systems are not providing useful, timely information on the human capital of firms and the performance of employees to their shareholders, investors, and other stakeholders. Even in this era of modern technological development, human resources are still viewed as an important asset that firms must report on in their financial statement to stakeholders. In Ghana, accounting for human resources has not received the needed attention from industry players, academia, the stock market. Therefore, it is necessary to discuss further the awareness of human resource accounting among university students.

The objective of the study

The study aimed to assess and ascertain the level of awareness of human resource accounting among tertiary students, especially those pursuing commerce and management studies. Also, the study aimed at examining whether tertiary students understand the concept of human resource accounting. Similarly, the study investigates whether human resource accounting is a major course of study at the tertiary education.

As a result, the study found answers to the following questions:

1. What is the level of awareness of Human Resource Accounting among Tertiary students?

2. To what extent do tertiary students understand Human Resource Accounting?

The null hypothesis was:

1. Tertiary students are not aware of Human Resource Accounting.

2. Tertiary students do not understand the concept of Human Resource Accounting. 


\section{LITERATURE REVIEW}

According to Ezeagba (2014), Human Resource Accounting can be traced back to the late 1950s in the research of Rensis Likert, a social psychologist, who coined the phrase Human Assets. This was eventually supplanted to the term Resources by scholars. The expression of human resources in accounting terms was a major factor in his work. When there was a growing awareness of accounting system behavioral difficulties, and changes in social values in general, Likert's ideal emerged. Traditional accounting has made it extremely difficult for investors to compare the Human Capital investment of a firm. Human resource accounting has gone through many transitions. In 1960-1966, there was a basic derivation of Human Resource Accounting concepts from related theories (Sharma \& Shukla, 2014).

In 1967-1970, Human resource accounting received some basic academic research development on the models. In 1971-1977, there was a significant growth of interest for the inclusion of Human resource accounting in the financial statements of entities, firms, or corporations. According to Savino, McGuire \& White (2012), interest in Human resource accounting declined in academia and corporations in late 1978-1980 due to the problematic nature of evaluating a firm's human capital investment in a competitive stock market.

Human resources have become a more significant and decisional element for the success of any corporate firm since the beginning of globalisation of business and services. Human Resource Accounting (HRA) is the systematic process and procedure related to accounting for expenditures on human resources as assets or capital to the firms (Enyi \& Akindehinde, 2014).

According to Enyi and Akindehinde (2014), the initial attempt to value human beings in monetary terms was conducted by Sir William Petty in 1691. Human resource accounting allows organizations to build, document, report, and develop a system to account for human capital performance (Fulmer \& Ployhart, 2014). It shows how a firm, or a corporation can positively or negatively affect their employees through their involvement and ensure that standard reporting captures all this critical information. The information presented indicates that Human Resource Accounting (HRA) relates to a concept of inherent or intangible assets of a firm.

Chung and D'Annunzio-Green (2018) noted that human resource accounts involve showcasing the talented and high caliber of employee's strengths that a firm has as an advantage over their competitors in the same industry or market. Ahmed, (2010) added that HRA deals with accounting for people an organization possesses as an asset. It is the assessment of a personnel cost and worth to an organization. It entails estimating the costs of recruiting, selecting, hiring, training and developing personnel in private and governmental sectors. HRA is a tool for accounting for increasing the managerial effectiveness of firms and corporations. HRA has three major roles; to offer reliable data on the cost and value of human resources to businesses; provide a framework for human resource decision-making and encourage decision-makers to reflect on human resources (Islam, Kamruzzaman \& Redwanuzzaman, 2013).

According to Greer (2021), majority of the human resource cost was recognized as an expense by the companies or firms. Organizations relied upon the traditional approach to account for human resources where a firm's investment in human resources is treated as expenses and recorded in the income statement instead of an intangible asset on the face of the financial statement.

Ibarra \& Cosico (2016), carried a similar study on awareness of HRA in the Philippines and found that firms follow the traditional way of accounting for human resource investments, where investments in human resources are expended in the income statement instead of a statement of financial position as an intangible asset. According to Garg (2017), identifying and measuring human resource data and disseminating that data to relevant parties is key to organizational development.

In time past, human resource accounting was primarily concerned with delivering human resource reports to managers and investors (Armstrong, 2006). However, consistent with Khan (2010), the author believes it should be included as part of an organization's reporting processes, capable of serving as a framework for human resource management standards. The ultimate objective of human resource accounting is not limited to accounting for personnel but to improve the way people contribute to the organization, society, and economic wellbeing.

The accountancy profession ignores the obvious importance of human beings in organisations as productive resources (Akintoye, 2012). The resources used in the production; materials, equipment, money, and procedures, will not function effectively and efficiently without the involvement of human resources or human beings.

Cascio and Boudreau, (2010) assert that human capital acknowledges that not all work is created equal. Businesses on the other hand, can improve the quality of that capital by investing in people. Employees' education, experience, and abilities all have economic worth for employers and the whole economy. Human capital is valuable since it is perceived to boost productivity and, consequently, profits. As a result, the more an organisation's investment in its employee's education or training, the more productive and profitable it will be (Frank \& Obloj, 2014).

Patro (2013), opined that an organisation is only as good as its employees or human resources suggestion: Human resources, which include directors, employees and executives are crucial to an organisation's success and are often managed by the Human Resource (HR) department of a firm. This division is responsible for hiring, managing, and optimizing employees. 
The human resource unit of a given organization is essentially responsible for: Human resources planning and strategy, recruitment, employee training and development, and reporting and analytics.

Cherian and Farouq (2013), also defined human resource accounting as "the process of identifying and measuring data regarding human resources and communicating this information to interested parties in the financial statement". In simple terms HRA, is an extension of the accounting principles of cost-to-revenue matching and data organization to communicate meaningful financial information.

Human resources can be seen as the most valuable assets that firms anchored on to provide goods and services to consumers (Cherian \& Farouq, 2013). Firms depend on human resources for their survival in this modern era of competitive environment. Technology and innovation may be vital, but without human involvement, firms can achieve nothing. Therefore, firms need to report on human resources (capital) as an asset on the face of the financial statement to their shareholders, investors, and other stakeholders.

\section{Theoretical Framework}

The article is anchored on stakeholder theory to explain why firms must encourage to disclose financial information on their human capital to the various stakeholder groups.

\section{Stakeholder Theory}

Varied stakeholder groups have different viewpoints on how a firm should disclose its financial information, according to stakeholder theory. As the name implies, stakeholders are groups of people i.e., investors, employees, or creditors who have a genuine relationship with a firm activity. Stakeholders are important players involved in investing, campaigning, procuring or patronizing the firms' services. The idea of a stakeholder theory is to personally identify the specific groups or individuals that firms must address in their needs in financial statement disclosure approach. Patro (2013), argued that an organisation is as good as its employees or human resources. Since stakeholders rely on relevant financial information to make decisions, Patro, (2013) argue that firms or organizations must endeavor to provide financial information on human capital that will support stakeholders' decision-making and enhance the firm image. According to Cascio and Boudreau, (2010), financial information can be investigated by looking at the decisions taken by the organization to meet the expectations of stakeholders. Financial information disclosures or report are seen as a way for firms to address the demands of stakeholders who are considered essential to the organization's future survival and existence. This emphasizes the importance of stakeholders' requirements and preferences on financial information disclosure. The firms would be seen as socially responsible if financial information on human capital is disclosed to suit the needs of shareholders, investors and other stakeholders. The stakeholder theory is linked to the incentive of improving a firm's image or goodwill by releasing financial information on human capital. Human resource accounting aims to provide a monetary value to the human capital used in the production of goods and services. According to Garg (2017), identifying and measuring human resource data and disseminating that data to relevant stakeholders is key to organizational development.

\section{METHODOLOGY}

The study concentrates on the awareness of Human Resource Accounting among tertiary students in the Greater Accra Region of Ghana. The study used an exploratory research design and quantitative research approach. Primary data was used for the research through administration of questionnaire. 300 students were randomly selected from 20 tertiary institutions in the Greater Accra Region to answer selfconstructed questionnaire with a five-point Likert scale. Strongly agree, agree, neutral, disagree, and strongly disagree were among the responses to the questions. Ibarra and Cosico (2016) as well as Ahmed (2010) employed similar study instrument.

There were three main sections to the questionnaire. The first section provides the demographic information of the study participants. Furthermore, in the second section of the questionnaire, closed-ended questions were constructed to allow the researcher to collect data from the respondents on their awareness of Human Resource Accounting. In the third section, open-ended questions were developed to test students' knowledge and understanding on human resource accounting. The goal was for the students to make a list of how or what could be done to ensure that Human Resource Accounting is promulgated and be encapsulated into the courses of study in the tertiary education. To attain this purpose, a sample of 20 Tertiary Institutions were selected through convenient sampling technique from a population of 37 topnotch and highly rated Tertiary Institutions in the greater Accra Region of Ghana.

Exploratory and the confirmatory factor analysis were used to establish the data validity which is a requirement for a quantitative study.

Out of the 300-questionnaires distributed, 200 were duly answered and returned. Out of 200 questions that were received, only 180 questionnaires were valid for further analysis. SPSS 20.0 statistical software was used to analyze the responses from the questionnaires. The statistical measures used to analyze the data were graphs, pie chart, bar chart and histogram to arrive at meaningful conclusions.

\section{RESULT}

Figure 1. illustrates the age demography of the respondents. From the chart, it could be seen that majority of the respondents were in the age bracket of 20-25, which represent $57 \%$, whereas $33 \%$ were between the ages of 25 and 30 . Furthermore, $4 \%$ were within the age brackets of $30-35$ whiles $6 \%$ were within $15-20$ age bracket. 
Figure 1. Age Demography

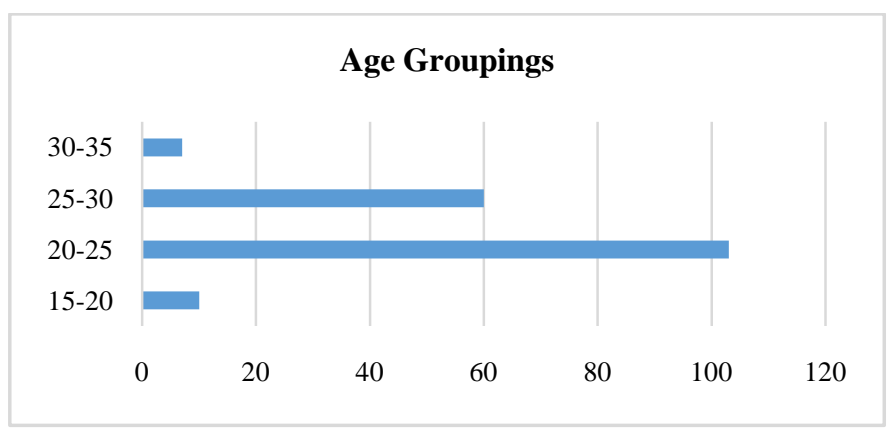

Source: Author's construct,(2021)

Figure 2 indicates the gender distributions of the respondents.

In terms of gender, results indicated that majority of the respondents were male representing $(56 \%)$ of the entire respondents. The remaining portion of $(44 \%)$ of the respondents were females in college and university student perusing commerce and management studies.

Figure 2. Respondents based on Gender Demography

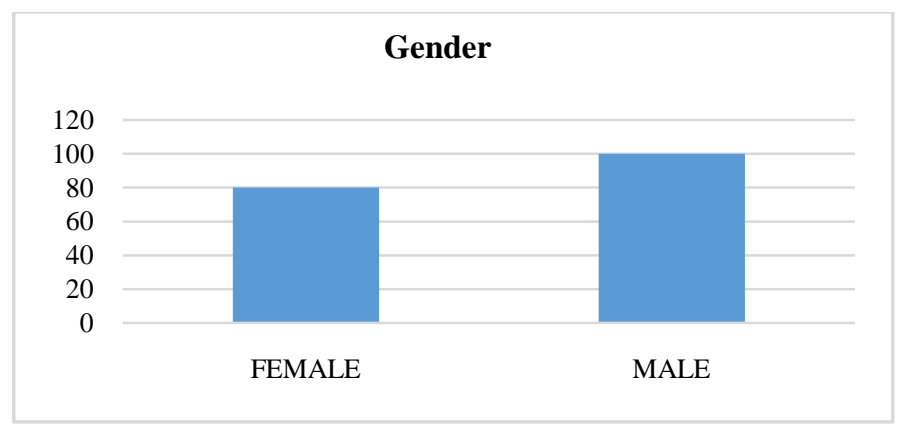

Source: Author's construct (2021)

\section{Respondents' Institutional affiliations.}

Figure 3 below, shows that majority of the respondent were University students pursuing Commerce and Management studies. This represents $61 \%$ of the respondents. Whereas, the remaining 39\% were Technical University students pursuing Commerce and management studies.

Figure 3. Respondents' affiliations

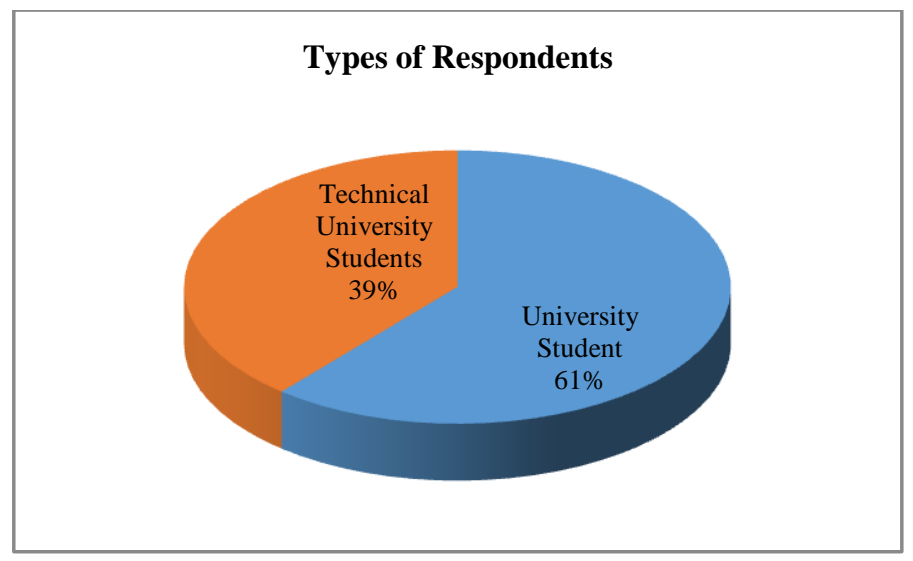

Awareness of human resource accounting among tertiary students

Figure 4 illustrates the objective of the study regards to the level of awareness of human resource accounting among tertiary students. This indicates that $(92 \%)$ of the respondents were aware of or have heard of Human Resource Accounting, while $6 \%$ of the respondents were unsure, $2 \%$ of the respondents remain neutral on human resource accounting. The result from the study supports the pervious study conducted by Ibara and Cosico, (2016).

Even though the level of awareness is high among the respondents, same cannot be said about the understanding on human resource accounting, $75 \%$ of the respondents indicate that they do not understand the human resource accounting concept, $11 \%$ indicate that they understand the human resource accounting concept, $6 \%$ remain neutral, $6 \%$ were unsure whilst $2 \%$ of the respondent disagreed to the assertion.

Human Resource Accounting (HRA) as a major course of study at the tertiary institution, $94 \%$ of the respondent stated that HRA is a major course of study in their programme. $6 \%$ of the respondents were agreed or unsure of the assertion.

As regards whether HRA should be studied at the tertiary level, $83 \%$ of the respondents prefer that Human Resource Accounting should be made a major course of study at the tertiary level, $11 \%$ of the respondents were unsure of the inclusion of HRA in the courses of study at the tertiary level, $3 \%$ of the respondents were neutral on the inclusion of HRA as a major course of study at the tertiary level.

Figure 4. Respondents based on the awareness of Human Resource Accounting

\section{Awareness of Human Resource Accounting}

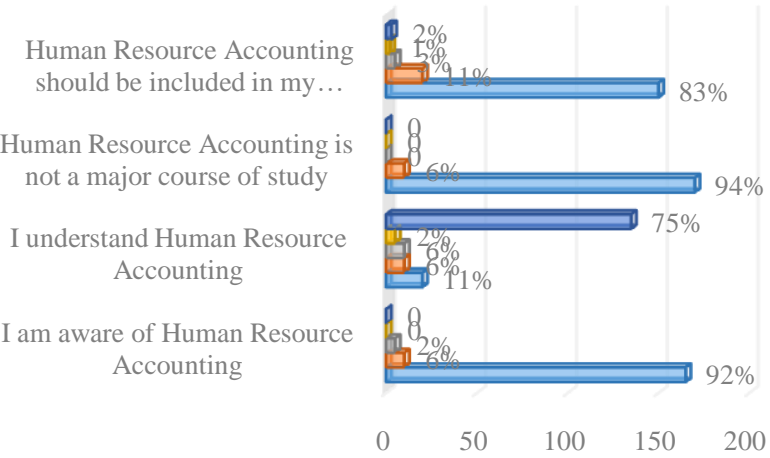

$\square$ Strongly disagree $\square$ Disagreed $\square$ Neutral $\square$ Agreed $\square$ Strongly agree

\section{CONCLUSION}

The study was undertaken to determine the level of student's awareness on Human Resource Accounting. The results from the study shows that there is a high level of awareness of Human Resource Accounting among the tertiary students. The 
study further noted that student do not really understand the human resource accounting concepts since is a new emerging are in accounting. In addition, the study revealed that human resource accounting is not embed in the student curriculum.

\section{RECOMMENDATION}

Human resources accounting is undoubtedly a developing discipline in the field of accounting. More need to be done on the concept of Human Resource Accounting. As society becomes more knowledge-based, firms are keeping an eye on their human capital, investing in employee recruitment and training. It is against this background that the researcher recommend that effort should made to integrate human resource accounting into the courses of study at the tertiary level. The researcher further recommend that the study should replicated elsewhere to uncover the importance of human resource accounting in industries.

\section{REFERENCES}

[1] Ahmed, A. C. A. (2010). Human resource accounting (HRA): Techniques and accounting treatment. http://works.bepress.com/asif_ahmed

[2] Akintoye, I. R. (2012). The Relevance of Human Resource Accounting to Effective Financial Reporting. International Journal of Business Management \& Economic Research, 3(4).

[3] Armstrong, M. (2006). A handbook of human resource management practice. Kogan Page Publishers.

[4] Avazzadehfath, F., \& Raiashekar, H. (2011). Decision-making based on human resource accounting information and its evaluation method. Asian Journal of Finance \& Accounting, 3(1), E14. http://dx.doi.org/10.5296/ajfa.v3i1.883

[5] Cascio, W., \& Boudreau, J. (2010). Investing in people: Financial impact of human resource initiatives. Ft Press.

[6] Cherian, J., \& Farouq, S. (2013). A review of human resource accounting and organizational performance. International Journal of Economics and Finance, 5(8), 74-83. http://dx.doi.org/10.5539/ijef.v5n8p74.

[7] Chung, K. L., \& D’Annunzio-Green, N. (2018). Talent management practices in small-and medium-sized enterprises in the hospitality sector: An entrepreneurial owner-manager perspective. Worldwide Hospitality and Tourism Themes. https://doi.org/10.1108/WHATT-10-2017-0065

[8] Collings, D. G. (2015). The contribution of talent management to organization success. The Wiley Blackwell handbook of the psychology of training, development, and performance improvement, 247. https://doi.org/10.1016/j.hrmr.2015.04.005

[9] Crane, A., \&Ruebottom, T. (2011). Stakeholder theory and social identity: Rethinking stakeholder identification. Journal of business ethics, 102(1), 77-87. https://doi.org/10.1007/s10551-011-1191-4

[10] Enyi, E. P., \& Akindehinde, A. O. (2014). Human resource accounting and decision making in postindustrial economy. International Journal, 2(1), 19-35. http://www.aripd.org/ijat

[11] Ezeagba, C. E. (2014). The need for inclusion of human resources accounting in the balance sheet. African Research Review, 8(2), 377-392. https://doi.org/10.4314/afrrev.v8i2.23
[12] Frank, D. H., \& Obloj, T. (2014). Firm-specific human capital, organizational incentives, and agency costs: Evidence from retail banking. Strategic Management Journal, 35(9), 1279-1301. https://doi.org/10.1002/smj.2148

[13] Fulmer, I. S., \& Ployhart, R. E. (2014). "Our Most Important Asset" a multidisciplinary/multilevel review of human capital valuation for research and practice. Journal of Management, 40(1), 161-192. https://doi.org/10.1177\%2F0149206313511271

[14] Gallagher, J. E., \& Hutchinson, L. (2018). Analysis of human resources for oral health globally: inequitable distribution. International dental journal,68(3), 183-189. https://doi.org/10.1111/idj.12349

[15] GARG, J. P. (2017). A Comparative Study of Human Resource Disclosure and Reporting Practices of Selected Public and Private Sector Banks in India. Clear International Journal of Research in Commerce \& Management, 8(11).

[16] Greer, C. R. (2021). Strategic human resource management. Pearson Custom Publishing.

[17] Groth, K. M., \& Swiler, L. P. (2013). Bridging the gap between HRA research and HRA practice: A Bayesian network version of SPAR-H. Reliability Engineering \& System Safety, 115, 33-42. https://doi.org/10.1016/j.ress.2013.02.015

[18] Ibarra, V. C., \&Cosico, C. A. (2016). Awareness of human resource accounting practices and costing: evidence from the Philippines. Global Journal of Business Research, 10(4), 27-42.

[19] Islam, M. A., Kamruzzaman, M., \& Redwanuzzaman, M. (2013). Human resource accounting: Recognition and disclosure of accounting methods \& techniques. Global Journal of Management and Business Research.

[20] Kamoche, K. (2011). Contemporary developments in the management of human resources in Africa. Journal of World Business, 46(1), 1-4.

[21] Khan, R. (2010). Human capital disclosure practices of top Bangladeshi companies. Journal of Human Resource Costing \& Accounting.

[22] Kiker, B. F. (1966). The historical roots of the concept of human capital. Journal of political economy, 74(5), 481-499.

[23] Mello, J. A. (2014). Strategic human resource management. Cengage Learning.

[24] Mohammed, J., Bhatti, M. K., Jariko, G. A., \&Zehri, A. W. (2013). Importance of human resource investment for organizations and economy: A critical analysis. Journal of Managerial Sciences Volume VII Number, 1, 128.

[25] Patro, C. S. (2013, December). The impact of employee engagement on organization's productivity. In 2nd International Conference on Managing Human Resources at the Workplace (pp. 13-14).

[26] Savino, D. M., McGuire, K. S., \& White, K. M. (2012). Human Asset Measurement: A Comparison of the Artifact-Based Approach versus Input Methods. Journal of Management Policy \& Practice, 13(1)

[27] Sharma, N., \& Shukla, H. (2014). Accounting Treatment f Human Resource as an Assets in the Companies. International Journal of Management, IT and Engineering, 4(11), 39.

[28] Slavec, A., \& Drnovšek, M. (2012). A perspective on scale development in entrepreneurship research. Economic and business Review, 14(1).

[29] Wardani, R. (2017, July). The Analysis of Interest to Treatment Outpatients Back Based on Management Resource Approach (Man, Money, Material, Machine, Method/5M). in proceeding surabaya international health conference 2017 (Vol. 1, No. 1). 